\title{
DOES THINNING AFFECT THE SOIL RESPIRATION IN SILVER FIR, BEECH AND SPRUCE PREDOMINATING ADULT FOREST STANDS?
}

\author{
Matjaž ČATER ${ }^{1}$
}

UDK $630 * 114: 630 * 242(497.4)$

\begin{abstract}
In three high karst forest complexes, same spatial design was applied to observe the effect of silvicultural treatment - the degree of mature stand removal on soil efflux. In every forest complex nine subplots were established during the time of experiment according to predominating tree species in growing stock of the mature canopy stand silver fir, Norway spruce and European beech. In 2012 silvicultural measures with different intensity $-50 \%$ and $100 \%$ removal of growing stock around the centre of the plot with minimal diameter of two tree heights were applied.

The seasonal pattern of $\mathrm{CO}_{2}$ efflux rates was mostly accountable by changes in soil temperature. Spatial heterogeneity in $\mathrm{CO}_{2}$ efflux rates was clearly reflected in management practice; release rates and recovery period were extreme in beech predominating sites, followed by the silver fir and norway spruce. It is our belief, that more oscillations may be expected in carbon release dynamics in the future, as the number of extreme weather events increases and the withdrawal of silver fir with its poor recruitment may have long-term consequences on these high karst high productive sites.
\end{abstract}

Keywords: soil efflux, silviculture, carbon release, beech, silver fir, Norway spruce

\section{INTRODUCTION}

The net flux of carbon $(\mathrm{C})$ in terrestrial ecosystems results from the balance between photosynthetic $\mathrm{CO}_{2}$ fixation and its release by ecosystem respiration. Northern forest ecosystems act as a carbon sink (Dixon et al., 1994; Goodale et al., 2002), but in the temperate forests respiration impacts the $\mathrm{C}$ balance more than photosynthesis (Valentini et al., 2000). Because the rate of $\mathrm{C}$ loss from soil is, to some extent, a function of temperature, the soil $\mathrm{C}$ balance is likely to be a sensitive indicator of climate change. The environmental and economic results from the balance between two large fluxes, $\mathrm{CO}_{2}$ fixation (photosynthesis) and $\mathrm{CO}_{2}$ release by ecosystem respiration benefits of this form

\footnotetext{
${ }^{1}$ Slovenian Forestry Institute, Večna pot 2, 1000 Ljubljana, Slovenia, matjaz.cater@gozdis.si Mendel University, Faculty of Forestry and Wood technology, Department of Silviculture, Brno, Czech Republic
} 
of $\mathrm{C}$ sequestration are huge, but to date, there has been no scientific basis on which to judge the theoretical and practical validity of these ideas.

$\mathrm{CO}_{2}$ movement or $\mathrm{CO}_{2}$ flux out of the soil is the primary function of soil respiration; soil $\mathrm{CO}_{2}$ flux is a significant component of the total atmospheric carbon balance. It is a physical process driven primarily by the $\mathrm{CO}_{2}$ concentration diffusion gradient between the upper soil layers and the atmosphere near the soil surface.

Soil $\mathrm{C}$ is not only an important part of the global $\mathrm{C}$ cycle, but also a critical part of ecosystem energy and nutrient cycles. The soil $\mathrm{CO}_{2}$ efflux consists of two components: soil organic matter (SOM)-derived $\mathrm{CO}_{2}$ and root-derived $\mathrm{CO}_{2}$ (Werth and Kuzyakov, 2008, 2010). Another important factor influencing the $\mathrm{CO}_{2}$ transport is atmospheric $\mathrm{CO}_{2}$, which diffuses into the soil. The abiotic carbonate-derived $\mathrm{CO}_{2}$ efflux has been considered of minor importance (Kuzyakov, 2010), but in semiarid and arid environments with carbonate-rich soils, efflux could be significant (Emmerich, 2003; Huxman et al., 2004). As soil temperature and soil moisture are among the most important factors controlling the $\mathrm{CO}_{2}$ efflux (Raich and Potter, 1995; Davidson et al., 1998; Buchmann, 2000), they explain sometimes less than $60 \%$ of the day-to-day variations in soil respiration (Schlentner and Van Cleve, 1985; Toland and Zak, 1994; Moren and Lindroth, 2002) suggesting, that other factors such as root nitrogen concentration, soil texture, and substrate quantity and quality may be involved. Consequently, large spatial and temporal variations in soil respiration rates have been found both within and between most temperate ecosystems (Buchmann, 2000; Soe and Buchmann, 2005). Seasonal variations in soil $\mathrm{CO}_{2}$ efflux have been observed in almost all ecosystems and have often been associated with changes in temperature, moisture, photosynthetic production and/or their combinations.

The main controlling factors may depend on the type of ecosystem and climate. Large spatial variability in soil $\mathrm{CO}_{2}$ respiration results from a large variability in soil physical properties such as soil water content, thermal conditions, porosity, texture, chemistry, biological conditions (fine-root biomass, fungi and bacteria), nutrient availability (nitrogen mineralisation) and others (disturbed history and weathering) (Hanson et al., 1999; Fang et al., 1998; La Scala et al., 2000; Xu and Qi, 2001; de Neergaard et al., 2002; Shibistova et al., 2002). Shibistova et al. (2002) showed a close connection between tree density and the soil $\mathrm{CO}_{2}$ efflux in an open boreal forest. Soil $\mathrm{CO}_{2}$ efflux rates were about double in the areas in proximity to trees than in the open areas, indicating that the development stage of trees (e.g. age and height) can explain some of the spatial patterns in the soil $\mathrm{CO}_{2}$ efflux in forests. Internal $\mathrm{C}$ fluxes within a forest ecosystem and their interaction with soil and atmosphere exchange processes may be addressed by using $\mathrm{C}$ isotopes.

The aim of our research was to identify differences in soil efflux before and after silvicultural measures (thinning) (1), to connect degree of carbon release according 
to the intensity of silvicultrural measure (2) and to compare soil effluxes in different stands with silver fir, Norway spruce and beech as predominating tree species (3).

\section{MATERIALS AND METHODS}

Research area is located in the Southern part of Slovenian Dinaric region, distributed along three forest management units: Trnovo, Snežnik and Rog. All studied forest complexes belong to Omphalodo-Fagetum with comparable structure, soil and climatic conditions (Table 1).

Table 1. Research area general features

\begin{tabular}{|c|c|c|c|}
\hline \multirow{2}{*}{ 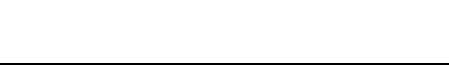 } & \multirow{2}{*}{ Trnovo } & \\
\hline & & Snežnik & $\operatorname{Rog}$ \\
\hline Area (ha) & 70 & 70 & 70 \\
\hline Location (UTM-WGS84) & $46^{\circ} \mathrm{N}, 13^{\circ} \mathrm{E}$ & $45^{\circ} \mathrm{N} ; 14^{\circ} \mathrm{E}$ & $45^{\circ} \mathrm{N} ; 15^{\circ} \mathrm{E}$ \\
\hline Altitude (m a.s.l) & $772-824$ & $731-774$ & $799-896$ \\
\hline Landscape morphology & \multicolumn{3}{|c|}{ Karst terrain with sinkholes, ridges and slopes } \\
\hline Bedrock & \multicolumn{3}{|l|}{ Limestone, dolomite } \\
\hline Soil characteristics & \multicolumn{3}{|c|}{ Litosol, Rendzic Leptosol, Cambisol, Luvisol } \\
\hline Temp med $\left({ }^{\circ} \mathrm{C}\right)$ & $9^{\circ} \mathrm{C}$ & $8^{\circ} \mathrm{C}$ & $8^{\circ} \mathrm{C}$ \\
\hline $\begin{array}{l}\text { Temp max }\left({ }^{\circ} \mathrm{C}\right) \text { (avg warm. } \\
\text { month) }\end{array}$ & & $12.5^{\circ} \mathrm{C}$ & $15.5^{\circ} \mathrm{C}$ \\
\hline $\begin{array}{l}\text { Temp min }\left({ }^{\circ} \mathrm{C}\right) \text { (avg coldest } \\
\text { month) }\end{array}$ & $4^{\circ} \mathrm{C}$ & $2.5^{\circ} \mathrm{C}$ & $2.5^{\circ} \mathrm{C}$ \\
\hline Rainfall (mm) & $2300 \mathrm{~mm}$ & $1600 \mathrm{~mm}$ & $1700 \mathrm{~mm}$ \\
\hline Forest type & \multicolumn{3}{|c|}{ Mixed silver fir, beech and spruce high forests. } \\
\hline Main management type & \multicolumn{3}{|l|}{ Uneven-aged forests. } \\
\hline Cutting - harvesting method & \multicolumn{3}{|c|}{ Freestyle technique; irregularshelterwood; selective cutting } \\
\hline Average living stock (m³/ha) & 292.0 & 442 & 351.6 \\
\hline Annual increment (m³/hayr) & 6.2 & 8.3 & 9.4 \\
\hline Basal area (average) ( $\left.\mathrm{m}^{2} / \mathrm{ha}\right)$ & 44.75 & 42.28 & 32.54 \\
\hline Stem density (N/ha) & 415 & 379 & 443 \\
\hline
\end{tabular}

In every forest complex nine subplots were established during the time of experiment according to predominating tree species in growing stock of the mature canopy stand - stands with silver fir, Norway spruce and European beech. In 2012, silvicultural measures with different intensity were applied with $50 \%$ and $100 \%$ removal of growing stock around the centre of the plot with minimal diameter of two tree heights (Figure 1). 

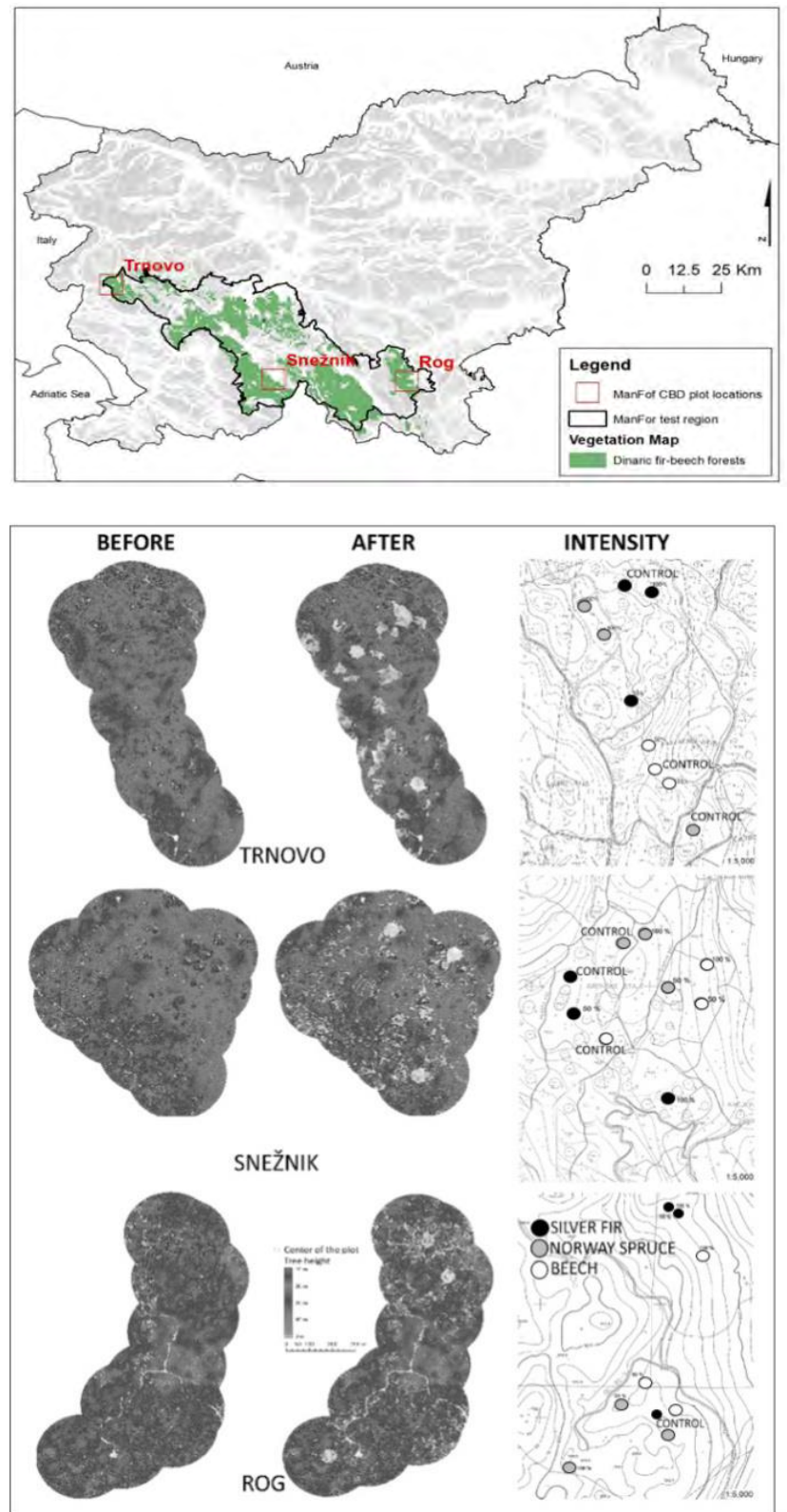

Figure 1. Location of research plots Trnovo, Snežnik and Rog - situation before and after silvicultural measure (100\% intensity, 50\% intensity and $0 \%$ - control with experiment design and equal share for every studied tree species (right). Tree height is presented with different colour (Author: A. Kobler, Slovenian Forestry Institute) 


\section{Soil efflux}

Manual measurement of soil efflux included a LI-6400 console with battery pack, soil chamber and soil temperature probe, connected to the console, allowing the temperature measurements to be integrated into the data set. The chamber concentration was automatically scrubbed to just below an ambient target, and measured as it raised to slightly above ambient concentration. This maintained the $\mathrm{CO}_{2}$ concentration gradient to within a few ppm of the natural, undisturbed value. Following each measurement, the intermediate flux data were fit with a regression, which is then used to compute the soil $\mathrm{CO}_{2}$ flux at the target ambient $\mathrm{CO}_{2}$ concentration (Čater and Ogrinc, 2011). Automated cycling ensures that $\mathrm{CO}_{2}$ flux measurements are accurate and repeatable. A pressure equilibration tube was used to eliminate pressure differentials and avoid chamber leaks, while air inside the chamber was thoroughly mixed while maintaining a constant pressure to assure consistently accurate data (Čater and Ogrinc, 2011).

Soil efflux with soil temperature was measured prior to silvicultural measures and after the event every month during growing season in years 2012, 2013 and 2014. On every plot five permanent locations have been determined to acquire reliable measurement response. Mean soil $\mathrm{CO}_{2}$ efflux $\left(R_{m}\right)$ measurement was correlated with mean soil temperature $\left(T_{m}\right)$ (separately for every tending intensity) using the exponential equation

$$
R_{m}=\beta \cdot e^{\alpha \cdot T_{m}}
$$

With $\alpha$ and $\beta$ as the regression coefficients.

The proportional change in $\mathrm{CO}_{2}$ efflux from $10{ }^{\circ} \mathrm{C}$ increase in temperature, known as Q10 was calculated according to Lloyd and Taylor (1994):

$$
Q_{10}=e^{10 \alpha}
$$

with $\alpha$ as a regression coefficient from the first equation [1]. $\mathrm{Q}_{10}$ was calculated individually for every silvicultural intensity measure and normalized for the temperature of $10^{\circ} \mathrm{C}\left(\mathrm{R}_{10}\right)$ according to following equation:

where $R_{S}$ is the soil $\mathrm{CO}_{2}$ efflux and $T_{S}$ soil temperature measured at each position. Differences between response groups were defined by the analysis of variance with Statistic for Windows software.

\section{RESULTS}

Plots within forest complex were evaluated before and after silvicultural measures with light intensity at the forest floor as the criterial parameter using hemispherical photos. Before stem removal forest stands indicated similar forest cover all over three forest complexes, all lower than $12 \%$ ISF (Table 2). 
Table 2. Light conditions before and after silvicultural measures

\begin{tabular}{|c|c|c|c|c|}
\hline & & Gap Fraction & Openness & Indirect Site Factor \\
\hline \multirow{4}{*}{ : } & before measure & $7.5 \pm 1.4$ & $7.5 \pm 1.4$ & $11.4 \pm 3.2$ \\
\hline & control & $5.6 \pm 0.9$ & $6.4 \pm 0.9$ & $9.2 \pm 1.4$ \\
\hline & $50 \%$ & $22.7 \pm 6.7$ & $25.2 \pm 7.6$ & $40.6 \pm 9.9$ \\
\hline & $100 \%$ & $42.0 \pm 6.5$ & $46.8 \pm 6.8$ & $75.4 \pm 8.5$ \\
\hline \multirow{4}{*}{ 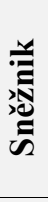 } & before measure & $8.1 \pm 2.9$ & $8.2 \pm 2.9$ & $12.3 \pm 4.7$ \\
\hline & control & $9.8 \pm 1.5$ & $10.7 \pm 1.9$ & $15.6 \pm 5.3$ \\
\hline & $50 \%$ & $18.2 \pm 7.2$ & $20.8 \pm 8.0$ & $36.3 \pm 5.4$ \\
\hline & $100 \%$ & $58.4 \pm 3.3$ & $58.5 \pm 3.2$ & $85.7 \pm 8.3$ \\
\hline \multirow{4}{*}{$\stackrel{+\infty}{\stackrel{0}{\alpha}}$} & before measure & $6.4 \pm 2.2$ & $6.40 \pm 2.2$ & $9.2 \pm 3.9$ \\
\hline & control & $5.9 \pm 1.2$ & $6.3 \pm 1.3$ & $8.1 \pm 1.4$ \\
\hline & $50 \%$ & $22.2 \pm 4.8$ & $23.3 \pm 5.5$ & $39.7 \pm 9.6$ \\
\hline & $100 \%$ & $49.3 \pm 5.6$ & $52.2 \pm 8.7$ & $65.2 \pm 9.8$ \\
\hline
\end{tabular}

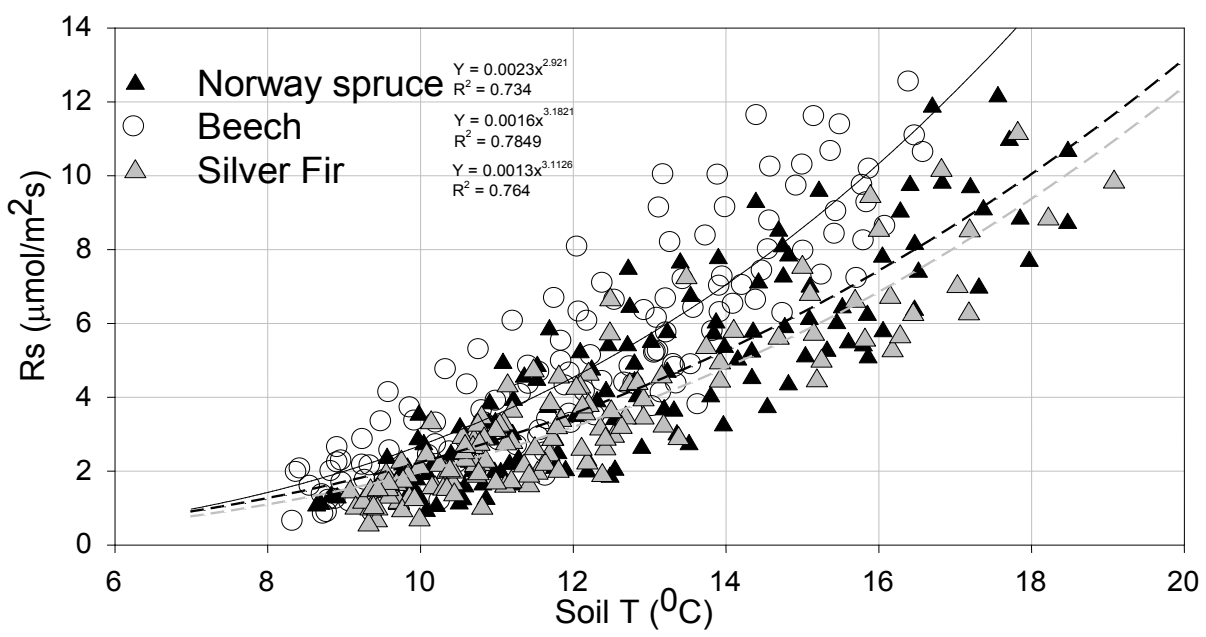

Figure 2. Soil efflux and soil temperature in different predominating tree species stands 
Dependence between soil respiration (Rs) and soil temperature differed according to predominating tree species. Response was different between beech and both spruce and fir stamds, while no differences were confirmed between fir and spruce (Figure 2).

\section{Soil efflux before and after silvicultural measures}

Differences before and after silvicultural measures were mostly pronounced in the period of first month after the event and were gradually becoming insignificant. Merged data from all plots and sites confirmed biggest significant changes on plots with predominating beech, smaller responses on plots with silver fir and smallest on plots with predominating Norway spruce. Because of annual dynamics and change regarding the temperature, dependence it was more illustrative to present the average difference between plots with different tending activity compared to the reference (control) plot after the performed silvicultural measures. Differences between beech and other two tree species were highly significant in all forest complexes $\left(\mathrm{p} \leq 0.001^{* * *}\right)$, while between fir and spruce differences were evident only for forest complex Trnovo $\left(\mathrm{p} \leq 0.0429^{*}\right)$ (Figure 3).

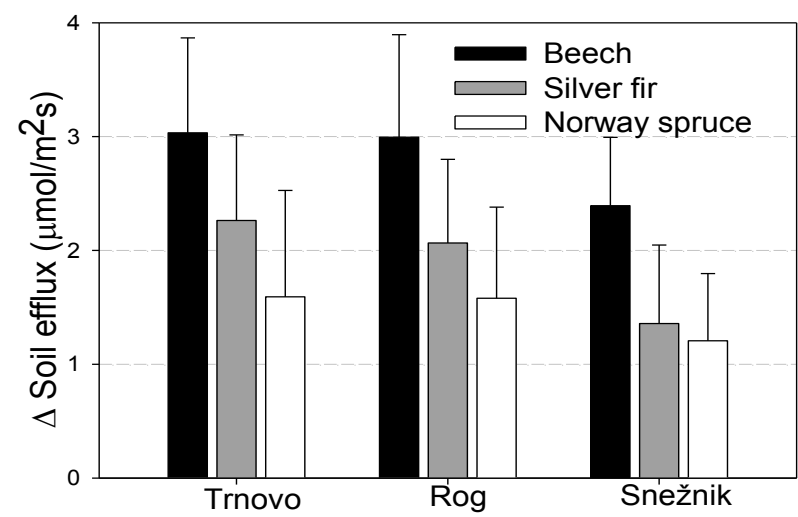

Figure 3. Difference in soil efflux - conditions before and after applied silvicultural measure according to predominating tree species; all plots included. Bars are standard errors.

\section{Carbon release and intensity of silvicultrural measure}

During the first month after applied measures the carbon release on all plots was significantly highest $(\mathrm{p} \leq 0.001 * * *)$ on plots with biggest measure intensity (e.g. $100 \%$ removal of mature stand), regardless of the particular tree species and forest complex. Highest rates between forest complexes were evidenced in beech predominating stands, followed by silver fir and spruce. The absolute release rates were again highest in forest complex Trnovo and smallest on plots of Snežnik (Figure 4). Both forest complexes (Tolmin and Snežnik) also differed in their response within same and comparable tree species and silvicultural measure group: 
Beech-100\% intensity, $\mathrm{p} \leq 0.008^{* *}$; Beech- $50 \%$ intensity, $\mathrm{p} \leq 0.0521^{\mathrm{Ns}}$; BeechControl, $\mathrm{p} \leq 0.0572^{\mathrm{NS}}$;

Fir- $100 \%, p \leq 0.000^{* * *}$; Fir-50\%, $\mathrm{p} \leq 0.001^{* *}$; Fir-Control, $\mathrm{p} \leq 0.0634^{\mathrm{NS}}$ and

Spruce- $100 \%, \mathrm{p} \leq 0.0421^{*}$; Spruce- $50 \%, \mathrm{p} \leq 0.000^{* * *}$; Spruce-Control, $\mathrm{p} \leq 0.0591^{\mathrm{Ns}}$.

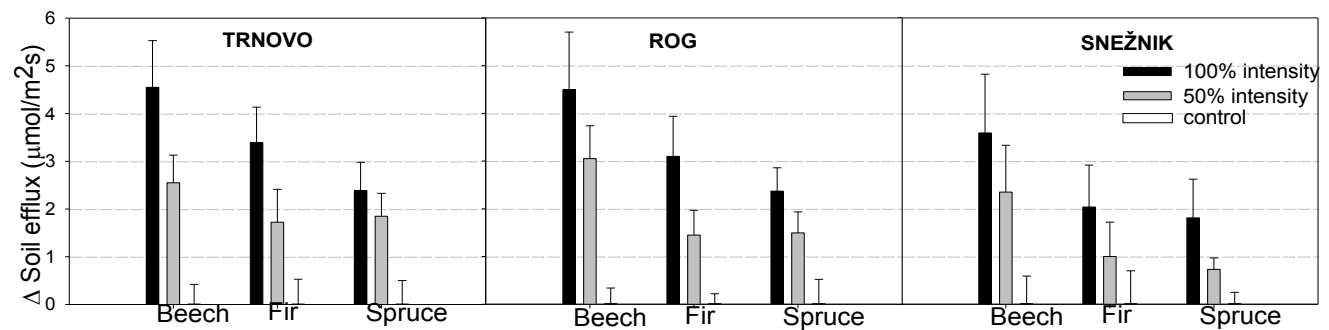

Figure 4. Intensity of silvicultural measure effect on soil efflux in stands with predominating beech, silver fir and spruce compared to control referential stands without applied silvicultural measure. Bars are standard errors.

Situation between Trnovo and Rog was similar, butthe response of fir with 50\% intensity measure indicated slightly smaller and insignificant carbon release rate compared to spruce plots in both forest complexes, while in plots of Snežnik rates on plots with $50 \%$ silver fir measure were higher than those of 50\% spruce, respectively.

\section{Response in time}

According to decreasing differences in efflux on plots with applied measures in time, the estimation about the time when effux would return to comparable control values was evaluated. In general, the shortest recovery rate was estimated for the beech predominating sites (within 15 months), followed by the silver fir (approximately 2425 months) and spruce sites (over 27 months), respectively (Figure 5).

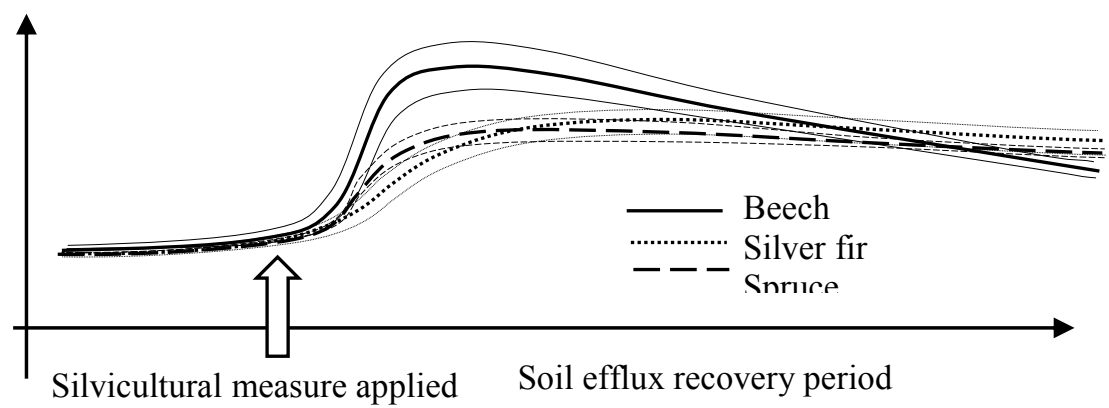

Figure 5. Schematic recovery period for different tree species reaching referential values 


\section{DISCUSSION}

Our study was conducted across three replicated sites harvested at the operational scale, and, while this undoubtedly increased the overall spatial and treatment variability, it increases the applicability of presented results to realistic forest management scenarios. The ecosystem respiration rates observed in our study $\left(5.0-10 . \mu \mathrm{mol} \mathrm{CO} / \mathrm{m}^{2} \mathrm{~s}\right)$ may be comparable to those reported for other beech forests in Europe (Epron et al., 2004; Søe and Buchmann, 2005; Knohl et al., 2008), as evaluated light conditions well described the intensity and also the efflux rate before and after applied measures on all plots. In our case, the seasonal variation in soil respiration is thought to be explained largely by soil temperature alone or a combination of soil temperature and water content (Davidson et al., 2006). The temporal variation in soil respiration in our study was well described by simple exponential functions (of temperature alone).

Spatial heterogeneity was affected by management practice, with a highest respiration rates on plots with $100 \%$ measure intensity, followed by the plots with lower management intensity. Higher respiration rates were related to lower average temperatures and microclimatic conditions in Snežnik than in Rog or Trnovo forest complex. Changes that were evidenced within same groups between forest complexes may be explained with different microclimatic conditions, in particular average air temperatures, as they were lowest in Snežnik, compared to other two forest complexes, while responses on Trnovo and Rog plots were more comparable.

Recovery period-comparison between control and managed plot-response indicated highest carbon release on plots with predominating beech, but also fastest recovery rate to the level of controlled plots with same tree species. Release rates of silver fir and spruce were smaller, but their recovery interval was significantly longer. In general, release differences in fir predominating stands were slightly higher to those in spruce dominated stands and were becoming gradually insignificant in time.

\section{CONCLUSIONS}

The seasonal pattern of $\mathrm{CO}_{2}$ efflux rates was mostly accountable by changes in soil temperature. Simple exponential functions including temperature alone accounted relatively well for the spatial variability over the investigated forest stands.

Spatial heterogeneity in $\mathrm{CO}_{2}$ efflux rates was clearly reflected in management practice.

Release rates and recovery period were extreme in beech predominating sites, followed by the silver fir and Norway spruce.

The amount of above ground litter may be a good indicator of soil respiration, as the high decomposition rate of litter associated with microbial respiration was a major component of soil respiration in a natural old growth forest reserve (Čater and Ogrinc 2011). It is our belief, that more oscillations may be expected in carbon release dynamics 
in the future, as the number of extreme weather events might increase and the withdrawal of silver fir with its poor recruitment may have long term consequences on this high karst high productive sites.

\section{Acknowledgement}

Presented research was financially supported by the Man-For C. BD. (LIFE 09 ENV/IT/000078) project and program research group Forest Biology, Ecology and Technology P4-0107 at the Slovenian Forestry Institute.

\section{REFERENCES}

Buchmann, N. Biotic and Abiotic Factors Controlling Soil Respiration Rates in Piceaabies Stands. Soil Biology and Geochemistry, 2000.32: s. 1625-1635.

Čater, M., Ogrinc, N. Soil respiration rates and $\delta 13 \mathrm{CCO}_{2}$ in natural beech forest (Fagus sylvatica L.) in relation to stand structure. Isotopes in Environmental and Health Studies, 2011.47(2): s. 221-237.

Davidson, E.A., Belk, E., Boone, R.D. Soil Water Content and Temperature as Independent or Confounded Factors Controlling Soil Respiration in a Temperate Mixed Hardwood Forest. Global Change Biology, 1998. 4: s. 217-227.

Davidson, E.A., Richardson, A.D., Savage, K.E., Hollinger, D.Y. A Distinct Seasonal Pattern of the Ratio of Soil Respiration to Total Ecosystem Respiration in a Spruce-dominated Forest. Global Change Biology, 2006. 12: s. 230-239.

Dixon, R.K., Brown, S., Houghton, R.A., Salmon, A.M., Trexler, M.C., Wisniewski, J. Carbon Pool and Flux of Global Forest Ecosystem. Science, 1994.263: s. 185-191.

Emmerich, W.E. Carbon Dioxide Fluxes in a Semiarid Environment with High Carbonate Soil. Agricultural and Forest Meteorology, 2003.116: s. 91-102.

Epron, D., Ngao, J., Granier, A. Interannual Variation of Soil Respiration in a Beech Forest Ecosystem over a six-year Study. Annal of. Forest Science, 2004. 61: s. 499-505.

Fang, C., Montcrieff, J.B., Gholz, H.L. Soil CO2 Efflux and its Spatial Variation in a Florida Slash Pine Plantation. Plant Soil, 1998. 205: s. 135-146.

Goodale, C.L., Apps, M.J., Birdsey, R.A., Field, C.B., Heath, L.S., Houghton, R.A., Jenkins, J.C., Kohlmaier, G.H., Kurz, W., Liu, S.R., Nabuurs, G.J., Nilsson, S., Shvidenko, A.Z. Forest carbon sinks in the Northern Hemisphere. Ecological Applications, 2002. 12: s. 891-899. http://dx.doi.org/10.1890/1051-0761(2002) 012[0891:FCSITN]2.0.CO;2

Hanson, P.J., Wullschleger, S.D., Bohlman, S.A., Todd, D.E. Seasonal and Topographic Patterns of Forest Floor $\mathrm{CO}_{2}$ Efflux from an Upland Oak Forest. Tree Physiology, 1999. 13: s. 1-15. 
Huxman, T.E., Snyder, K.A., Tissue, D., Leffler, A.J., Ogle, K., Packman, W.T., Sandquist, D.R., Potts, D.L., Schwinning, S. Precipitation Pulses and Carbon Fluxes in Semiarid and Arid Ecosystem. Oecologia, 2004.141: s. 254-268.

Knohl, A., Søe, A.R.B., Werner, L.K., Göckede, M., Buchmann, N. Representative Estimates of Soil and Ecosystem Respiration in an Old Beech Forest, Plant and Soil, 2008.302: s. 189-202.

Kuzyakov, Y., Sources of $\mathrm{CO}_{2}$ Efflux from Soil and Review of Partitioning Methods. Soil Biology and Biochemistry, 2003. 38: s. 425-448.

Lloyd, J., Taylor J. A. On the Temperature Dependence of Soil Respiration. Functional Ecology, 1994. 8(3): s. 315-323.

Morén, A.S., Lindroth, A. $\mathrm{CO}_{2}$ Exchange at the Floor of a Boreal Forest. Agricultural and Forest Meteorology, 2002. 101: s. 1-14.

Neergaard, A. de, Porter, J.R., Glorissen, A. Distribution of Assimilated Carbon in Plants and Rhizosphere Soil of Basket Willow (Salix viminalis L.). Plant and Soil, 2002.245: 307-314.

Raich, J.W., Potter, C.S. Global Patterns of Carbon Dioxide Emissions from Soils. Global Biogeochemical Cycles, 1995. 9: s. 23-36.

Scala, Jr.N.La, Marques, Jr.J. Pereira, G.T., Cora, J.E. Carbon Dioxide Emission Related to Chemical Properties of a Tropical Bare Soil. Soil Biology and Biochemistry, 2000. 32: s. 1469-1473.

Schlentner, R.E., Van Cleve, K. Relationship between CO2 Evolution from Soil, Substrate Temperature, and Substrate Moisture in Four Mature Forest Types in Interior Alaska. Canadian Journal of Forest Research, 1985. 15: s. 97-106.

Shibistova, O., Lloyd, J., Evgrafova, S., Savushkina, N., Zrazhevskaya, G., Arneth, A., Knohl, A., Kolle, O., Schulze, E.D. Seasonal and Spatial Variability in Soil $\mathrm{CO}_{2}$ Efflux Rates for a Central Siberian Pinussylvestris Forest. Tellus B Chemical and Physical Meteorology, 2002. 54: s. 552-567.

Søe, A.R.B., Buchmann, N. Spatial and Temporal Variations in Soil Respiration in Relation to Stand Structure and Soil Parameters in an Unmanaged Beech Forest. Tree Physiology, 2005. 25: s. 1427-1436.

Toland, D.E., Zak, D.R. Seasonal Patterns of Soil Respiration in Intact and Clear-Cut Northern Hardwood Forests, Canadian Journal of Forest Research, 1994. 24: s. 1711-1716.

Valentini, R., Matteucchi, G., Dolman, A.J., Schulze, E.D., Rebmann, C., Moors, E.J., Granier, A., Gross, P., Jensen, N.O., Pilegaard, K., Lindroth, A., Grelle, A., Bernhofer, C., Grünwald, T., Aubinet, M., Ceulemans, R., Kowalski, A.S., Vesala, T., Rannik, Ü., Berbigier, P., Loustau, D., Gudmundsson, J., Thorgeirsson, H., Ibrom, A., Morgenstern, K., Clement, R., Moncrieff, J., Montagnani, L., Minerbi, S., Jarvis, P.G. Respiration as the Main Determinant of Carbon Balance in European Forests. Nature, 2000. 404: s. 861-865. 
Werth, M., Kuzyakov, Y. ${ }^{13} \mathrm{C}$ Fractionation at Root-Microorganisms-Soil Interface, A Review and Outlook for Partitioning Studies. Soil Biology and Biochemistry, 2010. 40: s. 1372-1384.

Werth, M., Kuzyakov, Y. Determining Root-derived Carbon in Soil Respiration and Microbial Biomass Using ${ }^{14} \mathrm{C}$ and ${ }^{13} \mathrm{C}$. Soil Biology and Biochemistry, 2008. 40: s. 625-637.

$\mathrm{Xu}, \mathrm{M} ., \mathrm{Qi}, \mathrm{Y}$. Soil-surface $\mathrm{CO}_{2}$ Efflux and its Spatial and Temporal Variations in a Young Ponderosa Pine Plantation in Northern California. Global Change Biology, 2001. 7: s. 667-677. 